\section{AIDS Awareness and Educating Adolescents about Contraception Techniques: A Sociological Study of Parents and Teachers}

Amanpreet Singh

\section{Abstract}

This paper is based on partially exploratory and partially descriptive research design to find out AIDS awareness and agreement of parents and teachers on educating adolescents about contraception techniques. For this study 60 parents and 60 teachers were interviewed from 10 different Govt. Senior Secondary schools in district Sangrur, Punjab, India. The random sampling technique was used. The knowledge of AIDS among parents was found partial. Mothers showed lesser knowledge of AIDS in comparison to fathers. Teachers showed comprehensive knowledge of AIDS. Majority of respondents disagree on educating adolescents about contraception techniques. But all responded reported to be in agreement to provide full knowledge about AIDS to adolescents. The education of contraception for adolescent found to be associated with the knowledge of prevention from unwanted pregnancy. Parents and teachers showed propensity to provide such education to adolescents which advocates sexual abstinence until marriage. The plausible reason to such perception could be that in most of Indian societies there is taboo on sex or sex related discussion.

Keywords: Adolescents and AIDS, contraception knowledge to adolescents, teachers and AIDS, parents and AIDS

\section{Introduction}

Modern societies are grappling with problem of spreading of AIDS/HIV. AIDS is no longer treated only as medical problem but also as social problem. The spread of awareness about various facets of AIDS is seen to be the key for fighting this magnanimous epidemic. Majority of countries in Indian subcontinent comprise those societies which prohibit open discussion about sex or sexual diseases.

Society engineers the behaviour of every individual from cradle to grave. Even our basic instincts are satisfied in the manner in which our society dictates. When a child is born in a family, it is the duty of the parents to take care of the child. The role of parents is vital for child's growth. The basic behavior to which child is conditioned in his childhood is done by parents. The child is given 'toilet training' by his parents. This basic socialisation is guided according to the framework of basic values described in the culture of society. After childhood the stage of adolescence arrives. Adolescence is the most significant stage in human life as most of the socialisation occurs in this stage.

Adolescence came from the Latin word 'adolescere' which means 'to grow'. It is a transitional stage of physical and mental human development that occurs between childhood and adulthood (Macmillan Dictionary, 1981). This transition involves biological, social, and psychological changes. It is the period which is characterized by a combination of physical changes and is marked by the onset of puberty by rapid growth and the development of secondary sexual characteristics; similarly psychological changes occurs with the development of a sense of identity distinct from parents and self-worth, the exploration of new relationships with their peer groups, with the opposite sex, families and the community. It is also a time of exploration (of their own bodies, of one's capabilities and potential) and experimentation (in sexual relationships, alcohol and tobacco use).

At this stage, media and peers exert a powerful influence. Manifested by change, it is also a stage of extreme vulnerability where, for instance, alcohol use could easily slip into alcohol abuse if there is inadequate access to services and a supportive environment. The support and understanding of parents during this phase is critical in enabling them to meet these challenges. Adolescence is further complicated by the number of simultaneous nature of these changes. Different aspects of behaviour or physical appearance occur at various ages. Hurlock (1967) divides the adolescent period as follows: 


$$
\begin{array}{lc}
\text { Pre-adolescence } & 10-12 \text { years } \\
\text { Early-adolescence } & 12-16 \text { years } \\
\text { Late-adolescence } & 17-21 \text { years }
\end{array}
$$

For Indian subcontinent Pandey (1963) divided adolescent period into three stages:-.

$$
\begin{array}{ll}
\text { Early adolescence : } & 11 \text { to } 12.5 \text { or } 13 \text { year } \\
\text { Middle adolescence : } & 13 \text { to } 18 \text { years } \\
\text { Last adolescence : } & 18 \text { to } 21 \text { years. }
\end{array}
$$

As described above during adolescence period, due to onset of sexual maturation, child experiences changes in his body and mind. But there is no information input from teachers or parents to help child to cope with the changes occurring during this period. The adolescents face vacuum of knowledge and sexual maturation at the same time. As a consequence, adolescents become vulnerable because out of curiosity they are exploring different answers for the constant changes happening during this period. Parents and teachers avoid talking about sex; however it is most magnetic and confusing for adolescents.

NACO (2006) reported that in India people in the age group of 15-29 years account for 35.5 percent of total AIDS burden. This clearly indicates that young people are at high risk of getting HIV infection. It further elaborated that 73 percent of adolescents have misconceptions about modes of HIV transmission, tendency to experiment and an environment which makes discussing issues around sexuality taboo adds to their vulnerability.

There were number of studies which indicate vulnerability of adolescents. Mukhi (1983) reported that adolescents not only require education and guidance in understanding body changes and the reproductive system but also about other dimensions of growing up, thus properly designed curriculum is the need of the hour. Kaur (2000) revealed that most of the adolescents possess incomplete information about sex related matters and it is also found that the available source of information was devoid of proper information. Effective sex education may be thought of in its own forms of three 'R's- Respect, Responsibility and Restrain. Basu (1994) reported of early initiation of sexual activity among adolescents and they often

\section{6| Aman Preet Singh}

have sexual intercourse. This high-risk sexual behaviour resulted due to inadequate levels of knowledge of means of protecting their sexual health.

Blanc \& Rutenberg (1990) found that information, knowledge about risks to sexual health and means of preventing unhealthy or undesired outcomes are important for young people's sexual health. The adolescents are in need for information regarding safe and healthy sexual behaviours. Education is needed to counter teen pregnancy, STI, HIV/AIDS. Adolescents need complete knowledge of sources of risk and means of protection, and behaviours such as delaying age at first intercourse or abstinence till marriage, (Singh et al. 2005).

Biswas (1994) reported that a sizable proportion of unmarried students visit prostitutes. The reports of a survey conducted in a redlight area of Calcutta found that eight per cent of the customers of prostitutes were students including adolescents. On similar lines Gilada (1994) reported that 30 per cent of clients in Bombay red-light area were students and most of them were adolescents. Savara and Sridhar (1994) found that the prevalence of premarital relations among STD patients was high. The adolescents who suffered from STD/AIDS were found to be engaged in un-protected pre-marital sexual activities. Kim (2001) explored the negative sexual health behaviour of Korean adolescents. In order to save adolescents from the vices adolescents should be given appropriate knowledge.

Anandhi (2007) expressed deep concern about the incidence of HIV/ AIDS victims in Indian subcontinent who were adolescents. Due to rise in child sexual abuse, the increasing rate of pregnancy among adolescents, and the lack of information or misinformation about sexual health. In order to make healthy and responsible decisions about whether to have intercourse and how to protect themselves and their partners from unwanted pregnancies and STDs, young men and women need relevant information and education. The best way to prevent unintended pregnancy, STDs among adolescents was to provide them information and skills they need to use when they become sexually active. ( SIECUS ,1996; Holzner and Oetomo 2004)

Wellings et al (1995) suggested that as 'information is power', and in this high-risk day and age, adolescents need all the information they 
can get. To withhold information about sexuality puts all children at risk. Refusing to talk about sex does not mean that children are safe, that nothing bad will happen to them.

Young people who become sexually active during adolescence need proper information as the strong sexual instinct overrides young minds during adolescent period. In the absence of right guidance and information at this stage they are more likely to have multi-partner unprotected sex with high risk behaviour groups. Particularly vulnerable are impoverished, unemployed, under-employed, mobile/migrant youth, adolescents in sex work, young injecting drug users and street children as they are faced with high risk behaviour in their everyday life. They are also less likely to have information on the risks of getting HIV and means of protecting themselves from the infection. Such youth may face repeated risk of HIV infection through sexual exposure due to coercion or other compulsions. Young women are biologically more vulnerable to HIV infection than young men - a situation aggravated by their lack of access to information on HIV and even lesser power to exercise control over their sexual lives. Early marriage also poses special risks to young people, particularly adolescent girls. This is especially relevant for India, where majority of girls are married off by the time they are 18 years of age. Population Council (2006) reported that there are 1.5 billion young people between the age group of 10 and 24 years in world; $85 \%$ of them live in developing countries. It further revealed that about one in ten of all births worldwide are to adolescent women and a pregnant adolescent is two to five times more likely to die than adult women. Adolescents who are married also need proper guidance to avoid any health hazard. The right kind of sex education is thought to save adolescents and equip them to handle pressures from peer groups, media soaps, and internet. Sex education is needed to make adolescents wise so that they can handle their private sexual behaviour appropriately.

Parents and teachers play as primary agent of socialization for adolescents. Educating adolescents about contraception techniques is usually seen as a part of family planning policy and for combating AIDS. There is dearth of literature on the behavioural pattern parents and teachers on educating adolescents about contraception techniques. Sociological analysis of perception of parents and teachers on the issue of educating adolescents about contraception techniques will add vital inputs to the solution. The major objectives of this study are to access the knowledge of AIDS among parents and teachers, and to explore the level of agreement among parents and teachers on the issue of educating adolescents about contraception techniques.

\section{Methods of study}

The present study was conduced in the rural schools situated in district Sangrur, Punjab (India). Sangrur is in the southern part of Punjab and it is one of the old districts of Punjab. It lies in Malwa region of Punjab. It was decided to include teachers and parents of adolescents studying in Government senior secondary schools as in rural areas majority of schools are under Government control. Thus ten Government senior secondary schools were selected randomly from all Government senior secondary schools situated in Sangrur Tehsil. As the study aims at the adolescents of age group 14-19 years thus teachers and parents of these students were contacted. On examining the database of schools it was found that majority of adolescents were studying in $9^{\text {th }}, 10^{\text {th }}$ and $11^{\text {th }}$ classes. For the sampling a list of adolescents was prepared from the database of students studying in classes $9^{\text {th }}, 10^{\text {th }}$ and $11^{\text {th }}$. One male and female adolescent from each class was shortlisted on the random basis. Thus from each school a list of six (3 male and 3 female) adolescent students was prepared. The addresses of these students were obtained from school authorities. Fathers of male adolescents and mothers of female adolescents were contacted for the present study. A total of 60 i.e. 30 fathers and 30 mothers were interviewed for the study.

The teachers of classes $9^{\text {th }}, 10^{\text {th }}$ and $11^{\text {th }}$ were selected through random sampling. An attempt was made to give equal representation to both male and female teachers. From each school 3 male and 3 female teachers were involved to give equal representation to gender.

To generate data two interview schedules i.e. one for parents and one for teachers was constructed. For pretest of instrument a pilot study was conducted in two schools. A number of amendments were made in the interview schedule in the light of pilot study. Thus final interview schedule was used to collect data from parents and 
teachers. The data on profile of respondents was analyzed manually. However cross-tabulation of variables and calculation related to Person chi-square test was done with the help of SPSS on computer.

\section{Results}

\subsection{Description of Parents}

There were 70 percent fathers of male adolescents and 46.7 percent mothers of female adolescents in the age group 45-55 years. In age group 35-45 years there were 20 percent of fathers and 50 percent of mothers. There were three cases of fathers and one case of mother in age group 55+ years. Fathers were of higher age in comparison to mothers of female adolescents. Majority of mothers of female adolescents i.e. 93.3 were married and spouses living with them, while all fathers of male adolescents reported married and spouses living with them. There was 6.7 percent of mother of female adolescents who were widows. These were single parent families due to death of father and mothers were confronting social as well as financial problems. There were 20 percent of fathers and 26.7 percent of mothers who were illiterate. Majority i.e. 60 percent of fathers and half of mothers had educational level upto high school. There was 16.7 percent each of father and mother who reported to be graduates. One case of father and two mothers were post-graduates. Over all educational status of parents was of lower middle level.

There were 73.3 percent of fathers and 40 percent of mothers who reported to have annual income less than Rs 20,000. In income group of Rs 20,000 to 40,000 there were 23.3 percent of fathers and 43.3 percent of mothers. There were 16.7 percent of mothers in income group Rs 40,000 to 60,000 . There was only one case of father in income group $>$ Rs 80,000. Results showed that families of female adolescents had comparatively higher income than those of male adolescents. It is pertinent to mention here that for parents, gender of their children influences their choice of educational institute. During selection of school for their daughters factors like approachability and cheap educational avenue were considered, while for son English medium and expensive private schools were their first choice.

\section{0| Aman Preet Singh}

\subsection{Description of Teachers}

There were 16.7 percent each of male and female teachers who were in age group 25-35 years. In age group 35-45 years there were 26.7 percent of male teachers and 46.7 percent of female teachers. There were 46.7 percent of male teachers and 23.3 percent of female teachers who were in age group 45-55 years. In age group $>55$ years there were three cases of male teachers and four cases of female teachers.

Majority of the teachers were married. There was only a single case of male teacher and three cases of female teachers who were unmarried. Unmarried teachers were of younger age and were new entrants in the profession of teaching. There were majority of the teachers i.e.63.3 percent of male teachers and 23.3 percent of female teachers who were holding postgraduate degrees. However 30 percent of male teachers and 23.3 percent of female teachers were graduates. Two male and three female teachers were holding qualification related to computers. Only one female teacher had $\mathrm{PhD}$ degree. As the study was conducted in government schools so the qualification of all teachers was in accordance to the qualifications prescribed by government for teaching in schools.

The economic status of a family is determined by the total family income. Majority of teachers i.e. 70 percent and 76.7 percent had total family income (monthly) ranging from Rs 30,000 to 60,000 . There were three cases of male teachers who reported to have monthly income less than Rs 30,000. In income group of Rs 60,000 to 90,000 there were 10 percent of male teachers and 16.7 percent of female teachers. There were 10 percent of male teachers and two cases of female teachers who were in income group >Rs 90,000. Overall teachers belonged to higher economic strata of society.

\subsection{Knowledge of AIDS Among Respondents}

In order to access the knowledge of AIDS eight questions were asked to the respondents. First four statements were correct mode of spread of AIDS while rest four were incorrect mode of spread of AIDS. In the sample of parents there were two fathers and five mothers who 


\section{Dhaulagiri Journal of Sociology and Anthropology Vol. 4, 2010 | 201}

reported ignorance about AIDS. However all teachers reported to have heard about AIDS. The responses to the statements were recorded as yes, no and don't know.

Table 1: Distribution of parents according to their knowledge of AIDS

\begin{tabular}{|c|c|c|c|c|c|c|c|c|c|}
\hline \multirow{2}{*}{$\begin{array}{l}\text { Mode } \\
\text { of } \\
\text { spread } \\
\text { of } \\
\text { AIDS }\end{array}$} & \multicolumn{4}{|c|}{ Father } & \multicolumn{4}{|c|}{ Mother } & \multirow{2}{*}{$\begin{array}{l}p- \\
\text { valu } \\
\text { e }\end{array}$} \\
\hline & N.A & Yes & No & $\begin{array}{l}\text { Don't } \\
\text { Know }\end{array}$ & N.A & Yes & No & $\begin{array}{l}\text { Don't } \\
\text { Kno } \\
\text { w }\end{array}$ & \\
\hline $\begin{array}{l}\text { Sexual } \\
\text { Activity }\end{array}$ & $\begin{array}{l}2 \\
(6 . \\
7 \% \\
)\end{array}$ & $\begin{array}{l}28 \\
(93.3 \\
\%)\end{array}$ & $\begin{array}{l}0 \\
(0 \% \\
)\end{array}$ & $\begin{array}{l}0 \\
(0 \%)\end{array}$ & $\begin{array}{l}5 \\
(16.7 \\
\%)\end{array}$ & $\begin{array}{l}25 \\
(83.3 \\
\%)\end{array}$ & $\begin{array}{l}0 \\
(0 \%)\end{array}$ & $\begin{array}{l}0 \\
(0 \%)\end{array}$ & $\begin{array}{l}0.22 \\
8\end{array}$ \\
\hline $\begin{array}{l}\text { Blood } \\
\text { Transf } \\
\text { usion }\end{array}$ & $\begin{array}{l}2 \\
(6 . \\
7 \% \\
)\end{array}$ & $\begin{array}{l}27 \\
(90 \%)\end{array}$ & $\begin{array}{l}0 \\
(0 \% \\
)\end{array}$ & $\begin{array}{l}1 \\
(3.3 \% \\
)^{2}\end{array}$ & $\begin{array}{l}5 \\
(16.7 \\
\%)\end{array}$ & $\begin{array}{l}25 \\
(83.3 \\
\%)\end{array}$ & $\begin{array}{l}0 \\
(0 \%)\end{array}$ & $\begin{array}{l}0 \\
(0 \%)\end{array}$ & $\begin{array}{l}0.30 \\
6\end{array}$ \\
\hline $\begin{array}{l}\text { Sharin } \\
\mathrm{g} \\
\text { Needle } \\
\mathrm{s}\end{array}$ & $\begin{array}{l}2 \\
(6 . \\
7 \% \\
)\end{array}$ & $\begin{array}{l}27 \\
(90 \%)\end{array}$ & $\begin{array}{l}0 \\
(0 \% \\
)^{\prime}\end{array}$ & $\begin{array}{l}1 \\
\text { (3.3\% } \\
{ }^{2}\end{array}$ & $\begin{array}{l}5 \\
(16.7 \\
\%)\end{array}$ & $\begin{array}{l}24 \\
(80 \% \\
)\end{array}$ & $\begin{array}{l}0 \\
(0 \%)\end{array}$ & $\begin{array}{l}1 \\
(3.3 \\
\%)\end{array}$ & $\begin{array}{l}0.48 \\
1\end{array}$ \\
\hline $\begin{array}{l}\text { From } \\
\text { mother } \\
\text { to child }\end{array}$ & $\begin{array}{l}2 \\
(6 . \\
7 \% \\
\end{array}$ & $\begin{array}{l}28 \\
(93.3 \\
\%)\end{array}$ & $\begin{array}{l}0 \\
(0 \% \\
)\end{array}$ & $\begin{array}{l}0 \\
(0 \%)\end{array}$ & $\begin{array}{l}5 \\
(16.7 \\
\%)\end{array}$ & $\begin{array}{l}24 \\
(80 \% \\
)\end{array}$ & $\begin{array}{l}0 \\
(0 \%)\end{array}$ & $\begin{array}{l}1 \\
(3.3 \\
\%)\end{array}$ & $\begin{array}{l}0.27 \\
3\end{array}$ \\
\hline $\begin{array}{l}\text { Mosqu } \\
\text { ito Bite }\end{array}$ & $\begin{array}{l}2 \\
(6 . \\
7 \% \\
)\end{array}$ & $\begin{array}{l}4 \\
(13.3 \\
\%)\end{array}$ & $\begin{array}{l}21 \\
(70 \\
\%)\end{array}$ & $\begin{array}{l}3 \\
(10 \% \\
)\end{array}$ & $\begin{array}{l}5 \\
(16.7 \\
\%)\end{array}$ & $\begin{array}{l}1 \\
\text { (3.3\% } \\
\text { ) }\end{array}$ & $\begin{array}{l}21 \\
(70 \%)\end{array}$ & $\begin{array}{l}3 \\
(10 \% \\
)\end{array}$ & $\begin{array}{l}0.37 \\
9\end{array}$ \\
\hline $\begin{array}{l}\text { Kissin } \\
\mathrm{g}\end{array}$ & $\begin{array}{l}2 \\
(6 . \\
7 \% \\
) \\
\end{array}$ & $\begin{array}{l}3 \\
(10 \%)\end{array}$ & $\begin{array}{l}15 \\
(50 \\
\%)\end{array}$ & $\begin{array}{l}10 \\
(33.3 \\
\%)\end{array}$ & $\begin{array}{l}5 \\
(16.7 \\
\%)\end{array}$ & $\begin{array}{l}10 \\
(33.3 \\
\%)\end{array}$ & $\begin{array}{l}6 \\
(20 \%)\end{array}$ & $\begin{array}{l}9 \\
(30 \% \\
)\end{array}$ & $\begin{array}{l}0.02 \\
9\end{array}$ \\
\hline $\begin{array}{l}\text { Shakin } \\
\mathrm{g} \\
\text { Hand }\end{array}$ & $\begin{array}{l}2 \\
(6 . \\
7 \% \\
)\end{array}$ & $\begin{array}{l}0 \\
(0 \%)\end{array}$ & $\begin{array}{l}24 \\
(80 \\
\%)\end{array}$ & $\begin{array}{l}4 \\
(13.3 \\
\%)\end{array}$ & $\begin{array}{l}5 \\
(16.7 \\
\%)\end{array}$ & $\begin{array}{l}1 \\
(3.3 \% \\
)^{2}\end{array}$ & $\begin{array}{l}21 \\
(70 \%)\end{array}$ & $\begin{array}{l}3 \\
(10 \% \\
)\end{array}$ & $\begin{array}{l}0.45 \\
2\end{array}$ \\
\hline $\begin{array}{l}\text { Toilet } \\
\text { Seat }\end{array}$ & $\begin{array}{l}2 \\
(6 . \\
7 \%\end{array}$ & $\begin{array}{l}10 \\
(33.3 \\
\%)\end{array}$ & $\begin{array}{l}12 \\
(40 \\
\%)\end{array}$ & $\begin{array}{l}6 \\
(20 \% \\
)^{2}\end{array}$ & $\begin{array}{l}5 \\
(16.7 \\
\%)\end{array}$ & $\begin{array}{l}3 \\
(10 \% \\
)\end{array}$ & $\begin{array}{l}17 \\
(56.7 \\
\%)\end{array}$ & $\begin{array}{l}5 \\
(16.7 \\
\%)\end{array}$ & $\begin{array}{l}0.11 \\
1\end{array}$ \\
\hline
\end{tabular}

Table 1 depicts the distribution of parents according to their knowledge about AIDS. Majority of fathers identified correctly the right statements. Similarly majority of mothers responded correctly to first four statements. There was no significant difference between the

\section{2 | Aman Preet Singh}

knowledge of correct statements among fathers and mothers. In case of response to incorrect statements the level of knowledge among respondents was found to be low. There were $33.3 \%$ of fathers who reported of having no idea about spread of AIDS through kissing. Similarly there were considerable number of mothers who were not sure about the incorrect statements. The level of knowledge about AIDS among parents found to be partial. The comprehensive knowledge of AIDS was missing among both fathers and mothers. Mothers showed lower level of AIDS knowledge in comparison to fathers. There were many apprehensions found among parents of adolescents about spread of AIDS. The plausible reasons behind lack in comprehensive AIDS knowledge among parents could be lower educational status and rural background.

Table 2: Distribution of teachers according to their knowledge of AIDS

\begin{tabular}{|c|c|c|c|c|c|c|c|}
\hline \multirow{2}{*}{$\begin{array}{l}\text { Mode of } \\
\text { spread } \\
\text { AIDS }\end{array}$} & \multicolumn{3}{|c|}{ Male Teacher } & \multicolumn{3}{|c|}{ Female teacher } & \multirow{2}{*}{$\begin{array}{l}\mathrm{p}- \\
\text { value }\end{array}$} \\
\hline & Yes & No & $\begin{array}{l}\text { Don't } \\
\text { Know }\end{array}$ & Yes & No & $\begin{array}{l}\text { Don't } \\
\text { Know }\end{array}$ & \\
\hline $\begin{array}{l}\text { Sexual } \\
\text { Activity }\end{array}$ & $\begin{array}{l}30 \\
(100 \%)\end{array}$ & $\begin{array}{l}0 \\
(0 \%)\end{array}$ & $\begin{array}{l}0 \\
(0 \%)\end{array}$ & $\begin{array}{l}30 \\
(100 \%)\end{array}$ & $\begin{array}{l}0 \\
(0 \%)\end{array}$ & $\begin{array}{l}0 \\
(0 \%)\end{array}$ & - \\
\hline $\begin{array}{l}\text { Blood } \\
\text { Transfu } \\
\text { sion }\end{array}$ & $\begin{array}{l}30 \\
(100 \%)\end{array}$ & $\begin{array}{l}0 \\
(0 \%)\end{array}$ & $\begin{array}{l}0 \\
(0 \%)\end{array}$ & $\begin{array}{l}30 \\
(100 \%)\end{array}$ & $\begin{array}{l}0 \\
(0 \%)\end{array}$ & $\begin{array}{l}0 \\
(0 \%)\end{array}$ & - \\
\hline $\begin{array}{l}\text { Sharing } \\
\text { Needles }\end{array}$ & $\begin{array}{l}30 \\
(100 \%)\end{array}$ & $\begin{array}{l}0 \\
(0 \%)\end{array}$ & $\begin{array}{l}0 \\
(0 \%)\end{array}$ & $\begin{array}{l}30 \\
(100 \%)\end{array}$ & $\begin{array}{l}0 \\
(0 \%)\end{array}$ & $\begin{array}{l}0 \\
(0 \%)\end{array}$ & - \\
\hline $\begin{array}{l}\text { From } \\
\text { mother } \\
\text { to child }\end{array}$ & $\begin{array}{l}30 \\
(100 \%)\end{array}$ & $\begin{array}{l}0 \\
(0 \%)\end{array}$ & $\begin{array}{l}0 \\
(0 \%)\end{array}$ & $\begin{array}{l}30 \\
(100 \%)\end{array}$ & $\begin{array}{l}0 \\
(0 \%)\end{array}$ & $\begin{array}{l}0 \\
(0 \%)\end{array}$ & - \\
\hline $\begin{array}{l}\text { Mosquit } \\
\text { o bite }\end{array}$ & $\begin{array}{l}0 \\
(0 \%)\end{array}$ & $\begin{array}{l}30 \\
(100 \%)\end{array}$ & $\begin{array}{l}0 \\
(0 \%)\end{array}$ & $\begin{array}{l}29 \\
(96.7 \%)\end{array}$ & $\begin{array}{l}0 \\
(0 \%)\end{array}$ & $\begin{array}{l}1 \\
(3.3 \%)\end{array}$ & 0.000 \\
\hline Kissing & $\begin{array}{l}0 \\
(0 \%)\end{array}$ & $\begin{array}{l}30 \\
(100 \%)\end{array}$ & $\begin{array}{l}0 \\
(0 \%)\end{array}$ & $\begin{array}{l}0 \\
(0 \%)\end{array}$ & $\begin{array}{l}28 \\
(93.3 \%)\end{array}$ & $\begin{array}{l}2 \\
(6.7 \%)\end{array}$ & 0.150 \\
\hline $\begin{array}{l}\text { Shaking } \\
\text { Hands }\end{array}$ & $\begin{array}{l}0 \\
(0 \%)\end{array}$ & $\begin{array}{l}30 \\
(100 \%)\end{array}$ & $\begin{array}{l}0 \\
(0 \%)\end{array}$ & $\begin{array}{l}0 \\
(0 \%)\end{array}$ & $\begin{array}{l}30 \\
(100 \%)\end{array}$ & $\begin{array}{l}0 \\
(0 \%)\end{array}$ & - \\
\hline $\begin{array}{l}\text { Toilet } \\
\text { Seat }\end{array}$ & $\begin{array}{l}0 \\
(0 \%)\end{array}$ & $\begin{array}{l}28 \\
(93.3 \%\end{array}$ & $\begin{array}{l}2 \\
(6.7 \%\end{array}$ & $\begin{array}{l}0 \\
(0 \%)\end{array}$ & $\begin{array}{l}30 \\
(100 \%)\end{array}$ & $\begin{array}{l}0 \\
(0 \%)\end{array}$ & 0.150 \\
\hline
\end{tabular}

Table 2 shows the distribution of teachers according to their knowledge about AIDS. In case of male teachers majority had 
comprehensive knowledge about AIDS. There were only two male teachers who were doubtful about toilet seat being a mode of spread of AIDS. Majority of female teachers showed complete knowledge of AIDS. There was single female teacher who was doubtful about role of mosquito in spreading AIDS. There were two female teachers who were doubtful about kissing as a mode of spreading AIDS.

\subsection{Perception of Parents and Teachers about the worth of AIDS Awareness for Adolescent}

The awareness of various modes of spreading AIDS is regarded as the most significant tool to combat its spread. Parents and teachers act as the major source of socialization and information for adolescents. In the present study they were probed about their perception about the worth of AIDS awareness for adolescents.

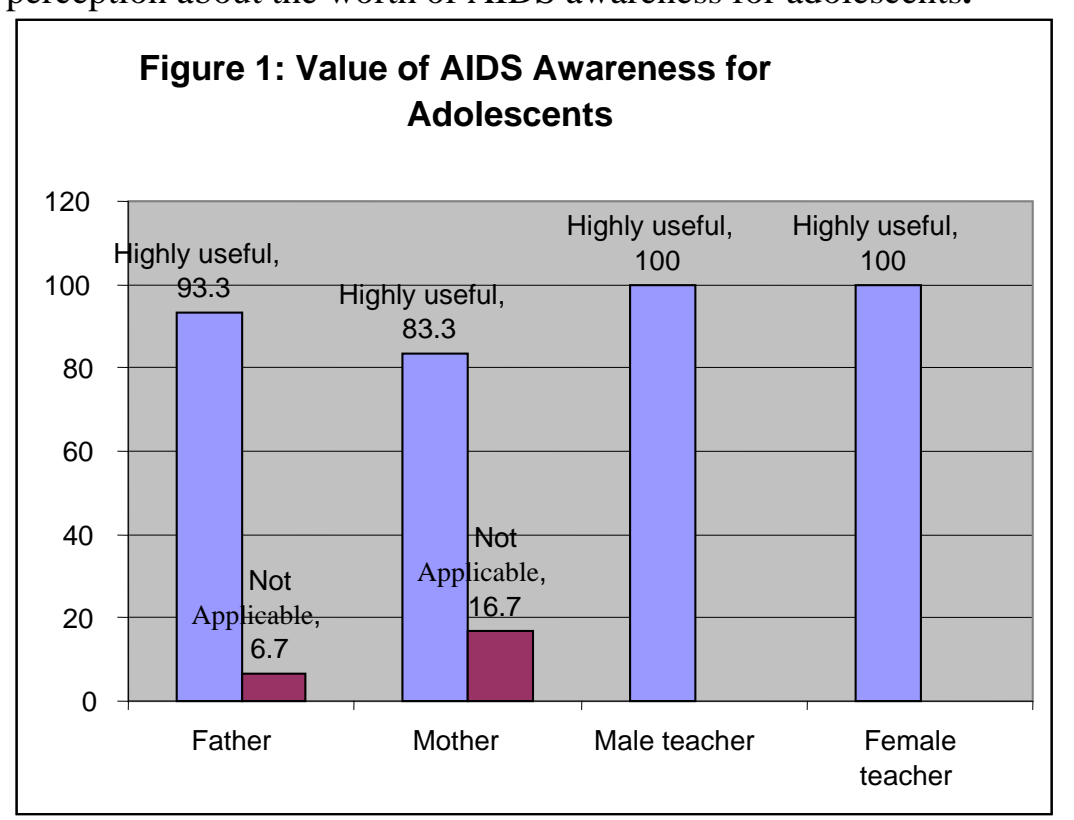

Figure 1 presents the perception of respondents about worth of AIDS awareness for adolescents. All parents who knew about AIDS reported its knowledge as highly useful for adolescents. Similarly all teachers reported AIDS knowledge as highly useful for adolescents. The incurability and fatal nature of AIDS was cited as the reason for its worth of awareness among adolescents.

\subsection{Knowledge Respondents \\ of contraception Techniques among}

The knowledge about condoms, birth control pills and copper-T was enquired among respondents. All male and female teachers reported of having knowledge about contraception techniques. All parents reported of knowledge about condoms and birth control pills. The knowledge of copper-T was found to be more in mothers i.e. $73.3 \%$ in comparison to fathers i.e. $60 \%$.

\subsection{Perception of Educating Adolescents About Contraception Techniques}

Table 3: Distribution of respondents according to their agreement on educating adolescents on contraception techniques

\begin{tabular}{|c|c|c|c|c|c|c|c|c|c|c|}
\hline \multirow{3}{*}{$\begin{array}{l}\text { Usefulness } \\
\text { of } \\
\text { contracepti } \\
\text { on } \\
\text { techniques } \\
\text { for } \\
\text { adolescent } \\
\text { s }\end{array}$} & \multicolumn{4}{|c|}{ Parents } & \multirow{3}{*}{$\begin{array}{l}p- \\
\text { val } \\
\text { ue }\end{array}$} & \multicolumn{4}{|c|}{ Teachers } & \multirow{3}{*}{$\begin{array}{l}\text { p- } \\
\text { valu } \\
\text { e }\end{array}$} \\
\hline & \multicolumn{2}{|c|}{ Male } & \multicolumn{2}{|c|}{ Female } & & \multicolumn{2}{|c|}{ Male } & \multicolumn{2}{|c|}{ Female } & \\
\hline & $\mathbf{N}$ & $\%$ & $\mathbf{N}$ & $\%$ & & $\mathbf{N}$ & $\%$ & $\mathbf{N}$ & $\%$ & \\
\hline $\begin{array}{l}\text { Highly } \\
\text { useful }\end{array}$ & 4 & $\begin{array}{l}13 . \\
3\end{array}$ & 1 & 3.3 & \multirow{3}{*}{$\begin{array}{l}0.3 \\
62\end{array}$} & 7 & $\begin{array}{l}23 . \\
3\end{array}$ & 4 & $\begin{array}{l}13 . \\
3\end{array}$ & $\begin{array}{l}0.02 \\
9\end{array}$ \\
\hline Useful & 8 & $\begin{array}{l}26 . \\
7\end{array}$ & 8 & $\begin{array}{l}26 . \\
7\end{array}$ & & $\begin{array}{l}1 \\
1\end{array}$ & $\begin{array}{l}36 . \\
7\end{array}$ & 4 & $\begin{array}{l}13 . \\
3\end{array}$ & \\
\hline No use & \begin{tabular}{l|}
1 \\
8
\end{tabular} & $\begin{array}{l}60 . \\
0\end{array}$ & $\begin{array}{l}2 \\
1\end{array}$ & $\begin{array}{l}70 . \\
0\end{array}$ & & $\begin{array}{l}1 \\
2\end{array}$ & $\begin{array}{l}40 . \\
0\end{array}$ & $\begin{array}{l}2 \\
2\end{array}$ & $\begin{array}{l}73 . \\
3\end{array}$ & \\
\hline \multicolumn{11}{|l|}{ Reasons } \\
\hline $\begin{array}{l}\text { Protection } \\
\text { from } \\
\text { STDIAIDS } \\
\text { and } \\
\text { pregnancy }\end{array}$ & 4 & $\begin{array}{l}13 . \\
3\end{array}$ & 9 & $\begin{array}{l}30 . \\
0\end{array}$ & \multirow{3}{*}{$\begin{array}{l}0.0 \\
06\end{array}$} & 7 & $\begin{array}{l}23 . \\
3\end{array}$ & 4 & $\begin{array}{l}13 . \\
3\end{array}$ & $\begin{array}{l}0.02 \\
9\end{array}$ \\
\hline $\begin{array}{l}\text { Protection } \\
\text { from } \\
\text { pregnancy }\end{array}$ & 8 & $\begin{array}{l}26 . \\
7\end{array}$ & 0 & 0.0 & & $\begin{array}{l}1 \\
1\end{array}$ & $\begin{array}{l}36 . \\
7\end{array}$ & 4 & $\begin{array}{l}13 . \\
3\end{array}$ & \\
\hline $\begin{array}{l}\text { Enhance } \\
\text { experiment } \\
\text { ation/ } \\
\text { Promotes } \\
\text { open sex in } \\
\text { society }\end{array}$ & $\begin{array}{l}1 \\
8\end{array}$ & $\begin{array}{l}60 . \\
0\end{array}$ & $\begin{array}{l}2 \\
1\end{array}$ & $\begin{array}{l}70 . \\
0\end{array}$ & & $\begin{array}{l}1 \\
2\end{array}$ & $\begin{array}{l}40 . \\
0\end{array}$ & $\begin{array}{l}2 \\
2\end{array}$ & $\begin{array}{l}73 . \\
3\end{array}$ & \\
\hline
\end{tabular}


Table 3 presents the perception of respondents on educating adolescents about contraception techniques. In case of parents there were $60 \%$ of fathers and $70 \%$ of mothers who regarded any education of contraception for adolescents as useless. These parents cited the reason that such knowledge among adolescents would enhance sexual experimentation and eventually promote open sex in society. There were 26.7 percent each of father and mother who regarded knowledge of contraception as useful for adolescents. There were $13.3 \%$ of father and one case of mother who stated that knowledge of contraception as highly useful for adolescents. There was statistically significant difference found among the rational of father and mother behind usefulness or highly usefulness of contraception techniques. The chi-square test revealed value of $\mathrm{p}$ as 0.00 .

Fathers who stated education of contraception techniques as useful stated that by this information unwanted pregnancy could be prevented. However fathers who treated knowledge of contraception techniques as highly useful stated that by this information STD/AIDS as well as unwanted pregnancies could be prevented. But all mothers who viewed contraception techniques as useful or highly useful stated that by this information adolescents could protect themselves from STD/AIDS as well as from unwanted pregnancy.

In case of teachers there were $40 \%$ of male teachers and $73.3 \%$ of female teachers reported education of contraception techniques for adolescents as useless. The statistically significant difference was found between opinions of female teachers with male teachers about educating adolescents on contraception techniques. Results reveled that male teachers showed more favourable attitude towards provision of contraception knowledge to adolescents than female teachers.

The teachers who deemed knowledge of contraception as useful stated that by this adolescents could prevent unwanted pregnancy. However teachers who reported information of contraception as highly useful stated that by this they could protect themselves from STD/AIDS as well as unwanted pregnancy. Results reveled that the knowledge of contraception was associated more with prevention of unwanted pregnancy than to protection from STD/HIV.

\subsection{Main findings}

In the present study following were the main findings:

- Knowledge of AIDS among parents was partial. Mothers lag behind in knowledge of AIDS in comparison to fathers. There were more mothers who reported of complete ignorance about AIDS than fathers. Parents were found skeptical about various modes of spread of AIDS.

- The knowledge of teachers about AIDS was found to be comprehensive. There was small number of teachers who were doubtful about one or two modes of spread of AIDS.

- All teachers and parents who knew about AIDS stated that its education for adolescents as significant. The main reason for this cited by respondents was fatality and incurability of AIDS.

- Majority of parents showed disagreement on educating adolescents about contraception techniques. Their main apprehension was that this knowledge would enhance sexual promiscuity and eventually open sex in society.

- Female teachers showed higher disagreement on educating adolescents about contraception techniques than male teachers. Sexual promiscuity and initiation of open sex in society were two main reasons cited by teachers.

- The association among agreement on educating adolescents about contraception techniques and protection from STD/AIDS found to be low. The prevention from unwanted pregnancy was viewed to be associated with knowledge of contraception techniques. 
The present study attempted to explore the AIDS awareness and agreement among parents and teachers on the issue of educating adolescents about contraception techniques. The low agreement on educating adolescents about contraception techniques reflected the patriarchal value system. The discussion about sex or any thing related to sex is seen as taboo in most of societies of Indian sub continent. Parents and teachers showed inclination towards provision of education which inculcate traditional values such as sexual abstinence until marriage and non-discussion of sexual issues. Results depicted that parents and teachers viewed education of contraception as means of prevention from pregnancy more than means for protection from STD/AIDS. In present world AIDS is assuming a serious problem. Present study points towards more deliberation on the modes of utilization of parents and teachers potential to fight the threat of AIDS among adolescents.

In most of the western countries, the policy on fighting AIDS is centered on generating awareness on enhancing use of condoms in masses. But in Indian subcontinent the policy on AIDS should take into account local socio-cultural values and beliefs. Results depicted that parents and teachers were reluctant to provide contraception information to their adolescent children. The study points towards fresh look on policies around AIDS so that it could truly benefit adolescents.

\section{Conclusion}

The present study revealed disagreement among parents and teachers on educating adolescents about contraception techniques. As parents and teachers plays most significant role in socialization of adolescents so the policy on protection of adolescents from AIDS should take their perception into consideration. The proper utilization of potentials of parents and teachers could help in formation of wholesome policy on combating spread of AIDS among adolescents.

\section{References}

Anandhi S (2007),’Sex Education Conundrum” Economic and Political Weekly, Volume 22 No.33, pp 67-69

Basu, D. P. (1994)” Appropriate Methodology for Studying Sexual Behaviour in India” Indian Journal of Social Work, Volume 55, No. 4, pp 573-588.

Biswas, R. (1994). "Blissful Ignorance: At what cost? "Nexus February-March. Cited in http://htc.anu.edu.au/pdfs/Nag1.pdf

Blanc, A. K. \& Rutenberg, V. (1990). Assessment of the Quality of Data on Age at first Sexual Intercourse, Age at first Marriage and Age at First Birth in the Demographic and Health Surveys. An Assessment of DHS-I Data Quality, DHS Methodological Reports (no 1) MD. Columbia: Macro International.

Gilada, I.S. (1994). The Bombay Model Goes International: AIDS Asia 6. Cited in Verma, R. K. (2004) Sexuality in the Time of AIDS: Contemporary Perspectives from Communities in India. Delhi: SAGE Publication.

Hurlock, E.B (1967). Adolescent Development. New York: McGraw Hill,

Holzner Brigitte M. and Oetomo Dede (2004),’Youth, Sexuality and Sex Education Messages in Indonesia: Issues of Desire and Control” Reproductive Health Matters, Volume. 12, No. 23, May, pp. 40-49

Kaur Amarjeet (2000). A Study of Behavioural Manifestation of Sexual Development of Urban and Rural Adolescent in Relation to their Attitude toward Sex. An unpublished $\mathrm{PhD}$ thesis submitted to the Faculty of Science (Home Science) in Child Development PanjabUniversity, Chandigarh

Kim , Y (2001). "Korean Adolescents Health Risk Behaviour and their Relationship with Selected Psychological Constructs". Journal of Adolescent Health, Volume. 29, No.4 pp 298-306. 
Macmillan Dictionary (1981) for Students Macmillan, Pan Ltd. page 14, cited in http://en.wikipedia.org/wiki/Adolescence

Mukhi Saria (1983). Sex Education: The Community, The Home, The Classroom" Eve's Weekly, Special Issue-Exploding Sexual Myths, April, cited in Jain, Neelima (1986) Behavioural dimensions of population education and sex education -A comparative study of youth in Punjab and H.P. An unpublished $\mathrm{PhD}$ thesis submitted in Faculty of Arts (Department of sociology) Panjab University, Chandigarh

NACO (2006), "National AIDS Control Programme Phase III (20062011)" cited in

http://www.nacoonline.org/upload/Publication/Strategy\%20a nd\%20Implementation\%20Plan\%20\%20NACO\%20Program me\%20Phase\%20III\%20(2006-2011)\%202006.pdf

Pandey ,Ram Shakal (1963). Our adolescents: Their interest and education, Agra. Luxmi Narain Aggarwal Education Publishers.

Population Council (2006)"'Unexplored Elements of Adolescence in the Developing World” Population Briefs, Vol. 12, No. 1. cited in http://en.wikipedia.org/wiki/Adolescent_sexuality

Savara, Mira and C.R. Sridhar (1994). "Sexual behaviour amongst different occupational groups in Maharashtra, India and the implications for AIDS education” Indian Journal of Social Work, Volume.55, No. 4, pp 617-632.

SIECUS (1996). Sexuality Information and Education Council of the United States, National Guidelines Task Force, Guidelines for retentive Sexuality Education: Kindergarten-12th Grade: second ed. New York. Cited in

www.guttmacher.org/pubs/psrh/full/3526103.pdf

Singh S., Bankole A. \& Woog V. (2005). ”Evaluating the need for sex education in developing countries: sexual behaviour, knowledge of preventing sexually transmitted infections/HIV and unplanned pregnancy" Sex Education: Sexuality, Society and Learning. Volume 5, No.4, pp307-331.

Wellings, K., Wadsworth, J., Johnson, A.M., Field, J., Whitaker, L.B.
(1995). "Provision of sex education and early sexual experience: The Relation Examined” British Medical Journal, 311 pp 417-420 cited in

http://www.plannedparenthood.org/files/PPFA/educationREAL-Evaluating.pdf 